\title{
INTEGRATED COASTAL AND MARITIME PLAN FOR OOSTENDE - DESIGN OF SOFT AND HARD COASTAL PROTECTION MEASURES DURING THE EIA PROCEDURES
}

\author{
Stefaan Gysens ${ }^{1}$, Julien De Rouck ${ }^{2}$, Koen Trouw ${ }^{3}$, Annelies Bolle ${ }^{4}$, Marc Willems ${ }^{5}$ \\ The coastal town Ostend in Belgium has his sea wall far in the sea. For this reason, the protection of the town against \\ storms is difficult. A harbor is situated in the city, with the harbor entrance close to the most important sea wall. \\ Integration of harbor constructions and coastal protections schemes is necessary.
}

Keywords: integrated coastal zone management, protection schemes, sea wall design

\section{INTRODUCTION}

The town of Oostende is the service centre of the Belgian coast. It is an attractive sea resort with a rather small harbour at present, although Oostende has been one of the important ports on the Southern North Sea for many centuries.

The old town centre with its seawards position compared to the rest of the coastline (see Figure 1) and low laying city centre at about the mean high water level, is protected against flooding by a seawall which was built some 130 years ago. Due to the seawall the erosion process of the beach has accelerated and the seawall does not meet present safety standards against breaching and overtopping, which makes it a critical point in the coastal protection along the Belgian coast.

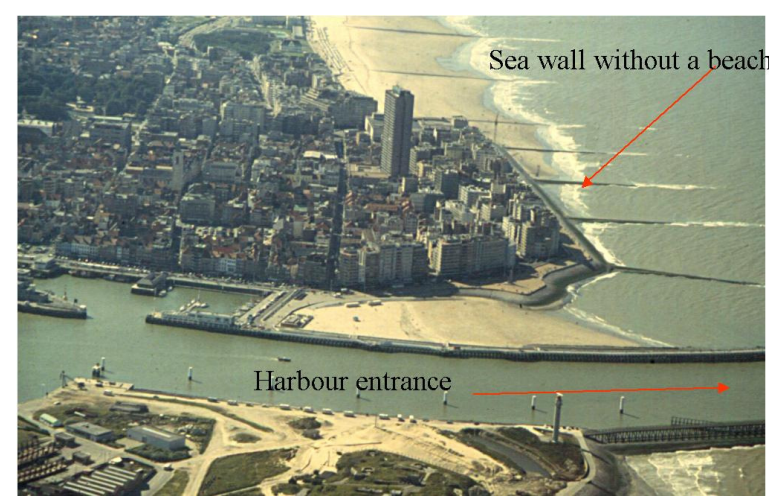

Figure 1 : Overview of the harbour entrance and the sea defence of the city of Oostende before 2004

The low seawall and its decades of influence on the beach erosion process, resulting in the absence of an important beach, cause high flood risks. During the storm of 19538 persons were killed in Oostende due to the flooding of the city. The material damage was huge as well. Also during yearly storms, water was swashed over the sea wall (e.g. Figure 2)

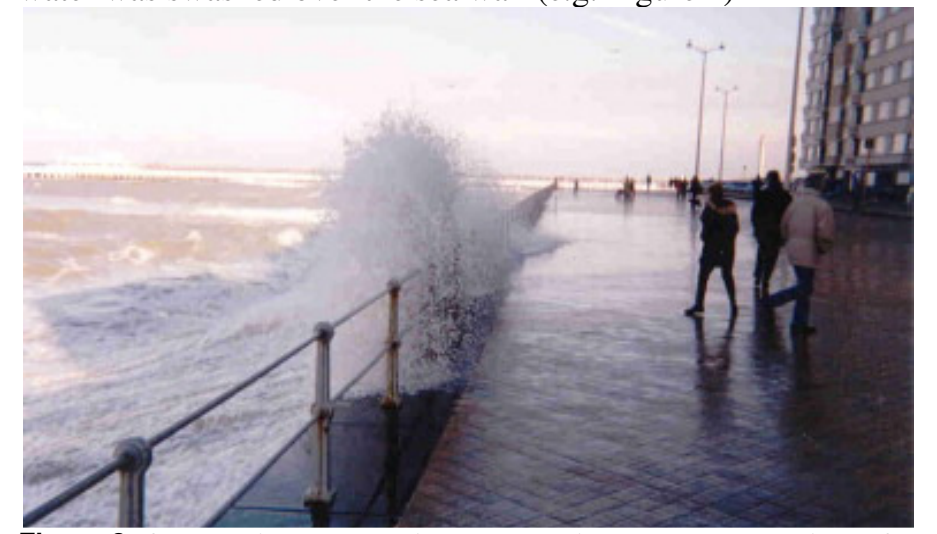

Figure 2: Overtopping event during a storm with small return period before 2004

\footnotetext{
${ }^{1}$ Agency for Maritime and Coastal Services (MDK), Coastal Division, Belgium, stefaan.gysens@mow.vlaanderen.be

${ }^{2}$ Ghent University (Ugent), Dept. of Civil Engineering, Belgium, julien.derouck@ugent.be

${ }^{3}$ Fides Engineering, Belgium, Koen.Trouw@fidesengineering.be

${ }^{4}$ IMDC, Belgium, annelies.bolle@imdc.be

${ }^{5}$ Flanders Hydraulics Research, Belgium, marc.willems@mow.vlaanderen.be
} 
In 2003 a panel of experts concluded that the flood risk of the city of Oostende starts from storms with a return period of 25 years and that the minimal allowed protection level should be a 1000 year storm with a maximum allowed overtopping discharge of 1 1/s/m De Rouck et al (2003).

Moreover important infrastructure works were executed in the inner harbour in the last decade, in order to make the harbour accessible to cruise ships, jumbo ferries and cargo ships with lengths up to $200 \mathrm{~m}$. All ships in the harbour of Ostend that are longer than $125 \mathrm{~m}$ or have a draught of more than $6.1 \mathrm{~m}$ are currently considered oversized, hence special conditions are stated for the accessibility of these vessels. The curved harbour access defined by two wooden piers is one of the main obstacles to limit the entry of bigger ships (see Figure 3).

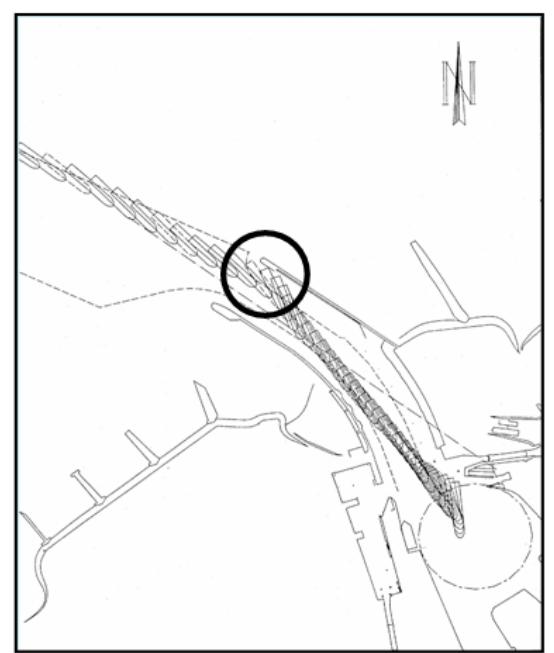

Figure 3 : Ship tracks in the original situation

However to receive these ships, important modification works of the harbour access are also necessary.

Detailed coastal and harbour engineering studies have been executed, in which coastal protection and the nautical problems have been approached in an integrated way.

The integrated coastal protection and harbour project finally comprises the construction of two new breakwaters (Figure 4), a beach nourishment scheme and the construction of a new section of the sea wall. The way to come to this scheme is presented in this paper.

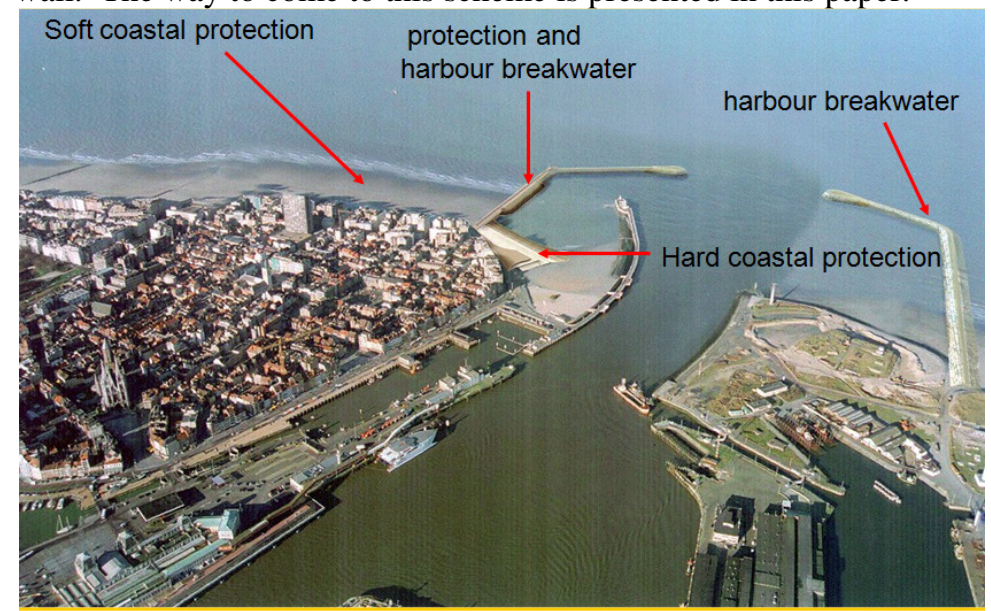

Figure 4: Integration of coastal protection and harbour construction (artist impression) 
HARBOUR ACCESS: DESIGN OF THE HARBOUR JETTIES AND NAVIGATION CHANNEL

In order to enable large vessels to enter the harbour, the existing harbour entrance needs to be broadened and two new harbour jetties need to be constructed (see Figure 4). In the strategic EIA two options for the western jetty are compared.

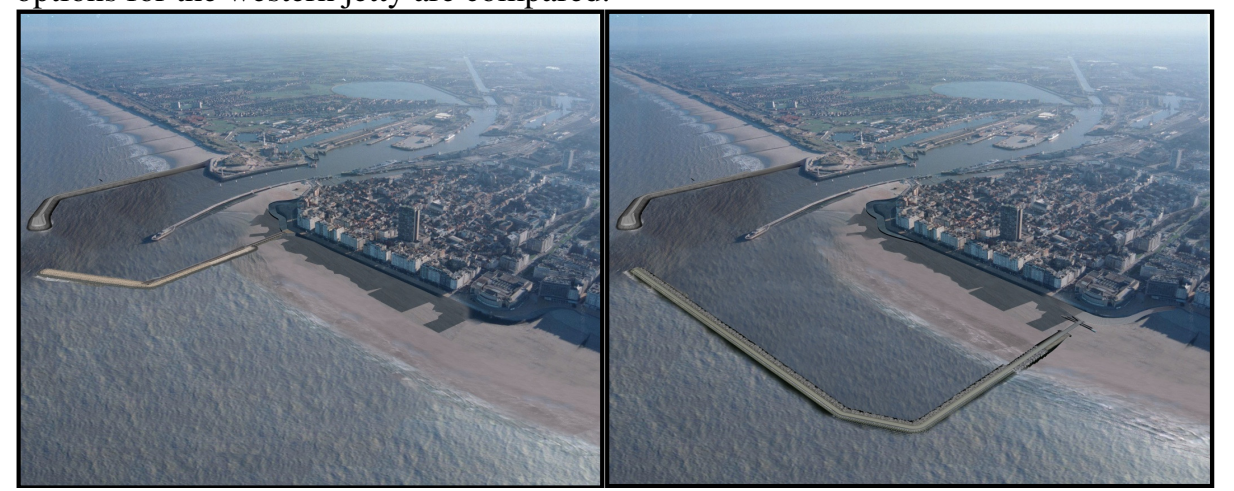

Figure 5:two main options for the harbour jetties: alternative A (short breakwater) and alternative B (long breakwater)

Alternative B was proposed by a NGO who proposed this solution to obtain a lower beach (beach berm height reduced with $1 \mathrm{~m}$ ) and to have a large axis in the city, prolonged into the sea. But, the strategic EIA pointed out that Alternative A is better since there is less disturbance of the coastal view and waves will still reach the beach, while in alternative B the beach will be more or less situated at still water.

The new jetties' chosen layout has been tested by simulations with a ship simulator. For this a mathematical current model was built with the aid of the software DELFT3D (Verelst et al, 2009). The simulations were completed by experienced captains and pilots. The distance between the heads is the minimum width needed to ensure a smooth and safe vessel passage. Any extra width was avoided so as not to unnecessarily increase wave and silt intrusion. The extended length of the new jetties provides enough slowing distance for entering ships. The current constriction of the current caused by this extension increases peak speeds by $25 \%$.

The new navigation channel will be redirected and deepened (long term vision: second phase from TAW -8.90 to $-10.40 \mathrm{~m})$.

More information can be found in Verhaeghe et al (2010).

For alternative A a mitigation variant is developed, shown in red on Figure 6.

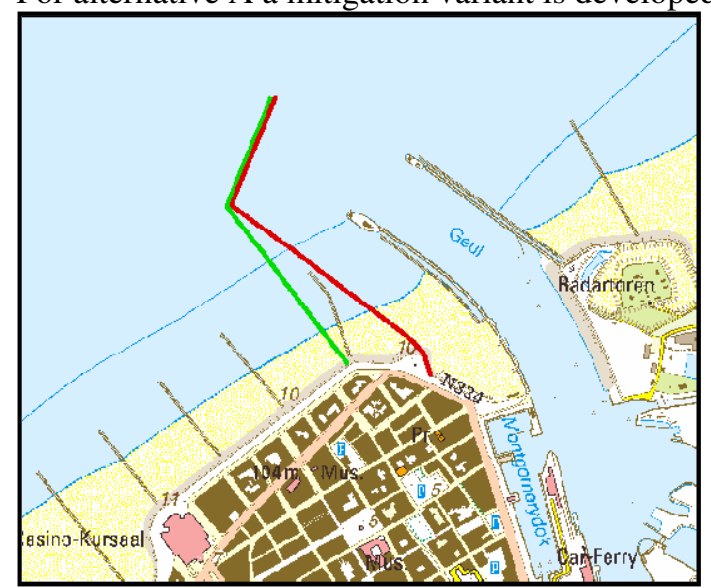

Figure 6:Alternative $\mathbf{A}$ (in green) and mitigation variant (red)

The mitigation variant had some advantages for town planning: the historical city layout is better preserved and there is a more clear distinction between harbour and city. In the red variant the sea wall is protected over a longer distance by the beach. The two variants are also examined from a nautical view. For the currents and possible banc suction, it is clear that there is no difference (the seaward stretch remains the same). The green variant will dissipate better the in waves entering the harbour. The red variant might result in a choppy sea since for some wave directions incoming and reflected waves are superimposed (cf. Figure 7). 


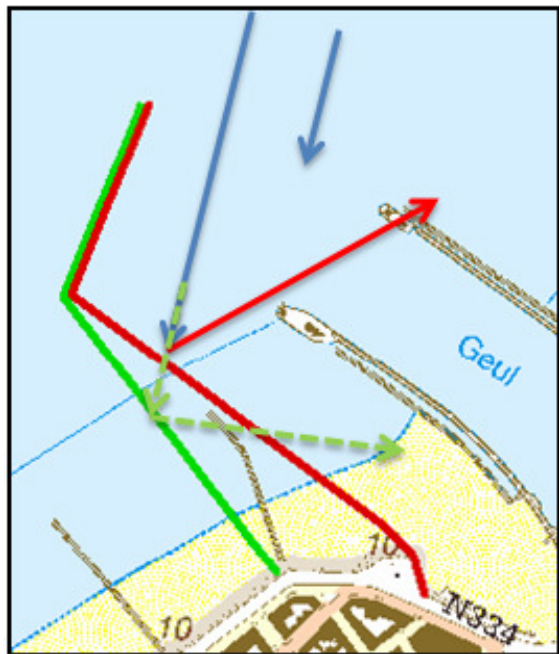

Figure 7 Effect of harbour jetty orientation on wave climate in the harbour

Finally a compromise between the two variants was chosen (see below).

\section{DESIGN OF A NEW BEACH}

In the 2003 situation the calculated overtopping discharge during a storm with return period of 1000 year was 100 to 2001/s/m. In anticipation of the execution of a sustainable project an emergency beach nourishment was necessary to increase the safety level to a more acceptable level (protection against a 100 year storm) was executed in 2004.

The new beach which will protect the city from flooding by a storm with a return period of 1000 year, must be high and broad enough and sufficiently stable, in order to temper the storm waves and prevent flooding of Oostende city centre.

The most important stabilising element for this beach is a dam construction that is perpendicular to the coastline at the north east side of the new beach This dam (breakwater) reduces longshore transport of sand that is mainly directed from south west to north east. This has a stabilising effect on the new beach and avoids sedimentation in the access channel.

Two types of mathematical morphological models have been used for the design of the new beach. The first type simulates the behaviour in cross profile during a 1000 year storm: the Dutch beach erosion DUROSTA software. The second type simulates the beach morphology up to 10 years after construction: the one-line model LITPACK and the multi-line model Pontos (Technum, IMDC, Alkyon,2004, Bolle et al, 2008).

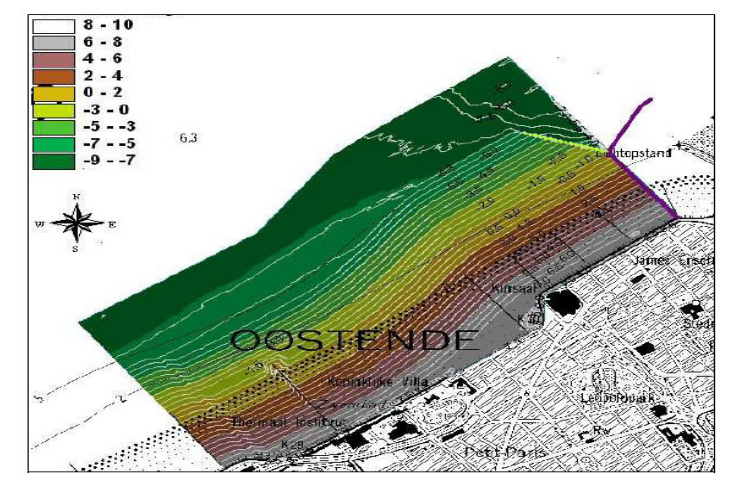

Figure 8: design of the new beach 


\section{DESIGN OF THE NEW SEAWALL}

In future a small stretch of the existing sea wall will be located between the new harbour breakwaters. This area is directly subject to waves penetrating via the harbour entrance (see Figure 4). There is no room for a new beach with a protection level for a 1000 year storm, therefore it was necessary to look for an alternative means of coastal protection which not only had to comply with technical requirements, but which could also be incorporated appropriately in the historical urban environment of this tourist beach resort. The solution is a stilling wave basin (SWB) with a smooth dike structure, as presented on ICCE 2006 (Geeraerts et al, 2006).

First possible erosion of the beach was calculated. With the post-storm bathymetry the wave penetration was determined (using Boussinnesq modelling). Finally physical tests were used to optimise the seawall layout in order to reduce the wave overtopping discharge to a maximum allowable discharge. The optimal layout consisted of a dike slope with a vertical (partly open) wall followed by a large kind of basin with at the landward site a flexible storm wall.

In plan view basically two alternatives are examined: option 1 (Figure 9) were the new seawall follows the contours of the actual square and option 2 (Figure 10) were the seawall points more seawards and were the start of the harbor breakwater is directed a little bit more eastwards. Option 1 is better for the preservation of the actual, historical situation, while option 2 has more possibilities for new architecture.

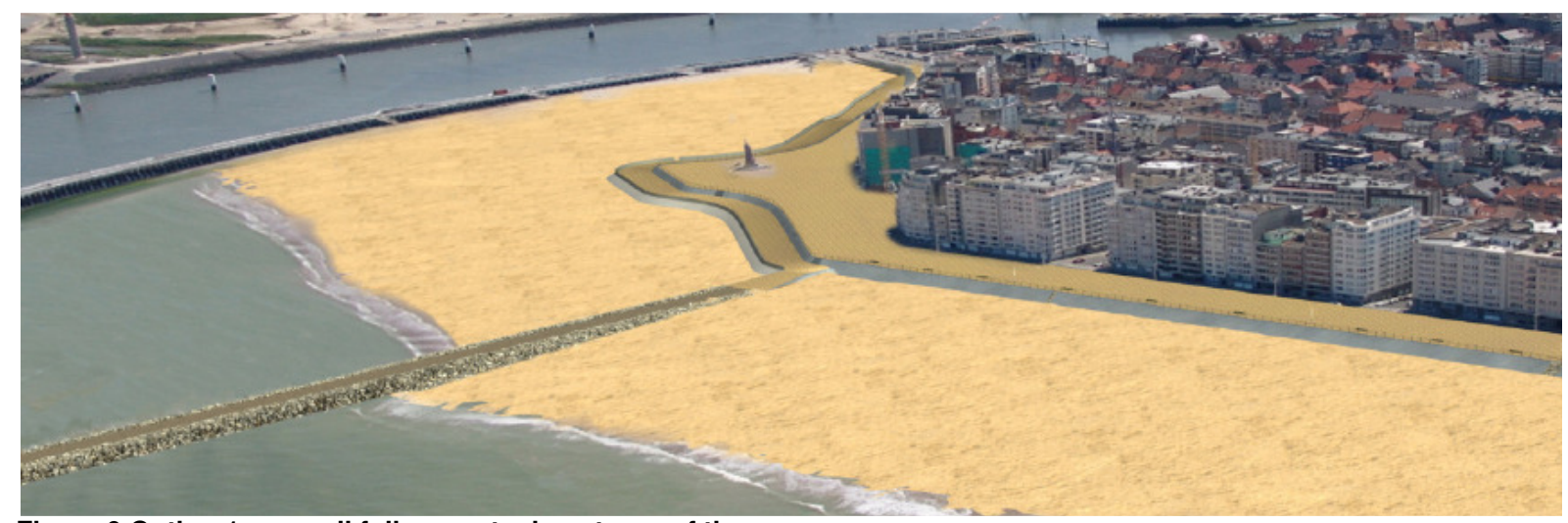

Figure 9 Option 1 sea wall follows actual contours of the square

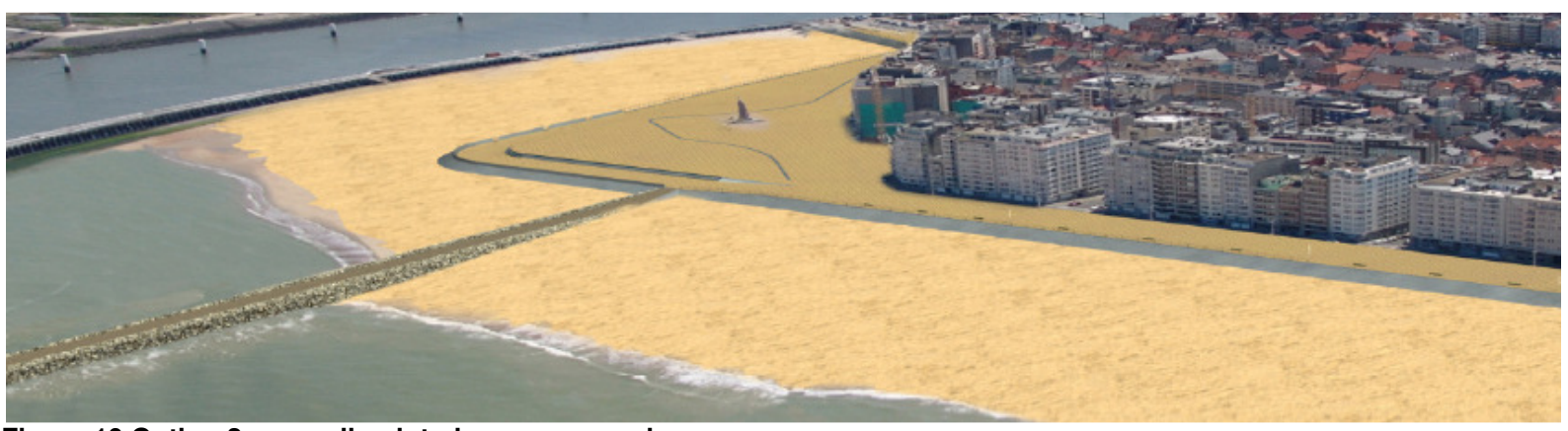

Figure 10 Option 2 sea wall pointed more seawards

\section{Morphology}

During normal conditions only low waves will penetrate between the existing and new western harbour breakwater. However, during storms which penetrate directly in between the opening between the breakwaters, important erosion in front of the new seawall can occur. This erosion will cause higher waves at the toe of the new seawall, with consequently higher overtopping discharges.

The morphodynamics during a storm in this complex area is difficult to predict. As an estimate, the beach erosion is calculated with Durosta (Steetzel, 1993). It is well known that this neglects possible longshore evolutions, but these effects are estimated with expert judgement. 
First the design bottom and different profiles to be evaluated are defined (Figure 11):

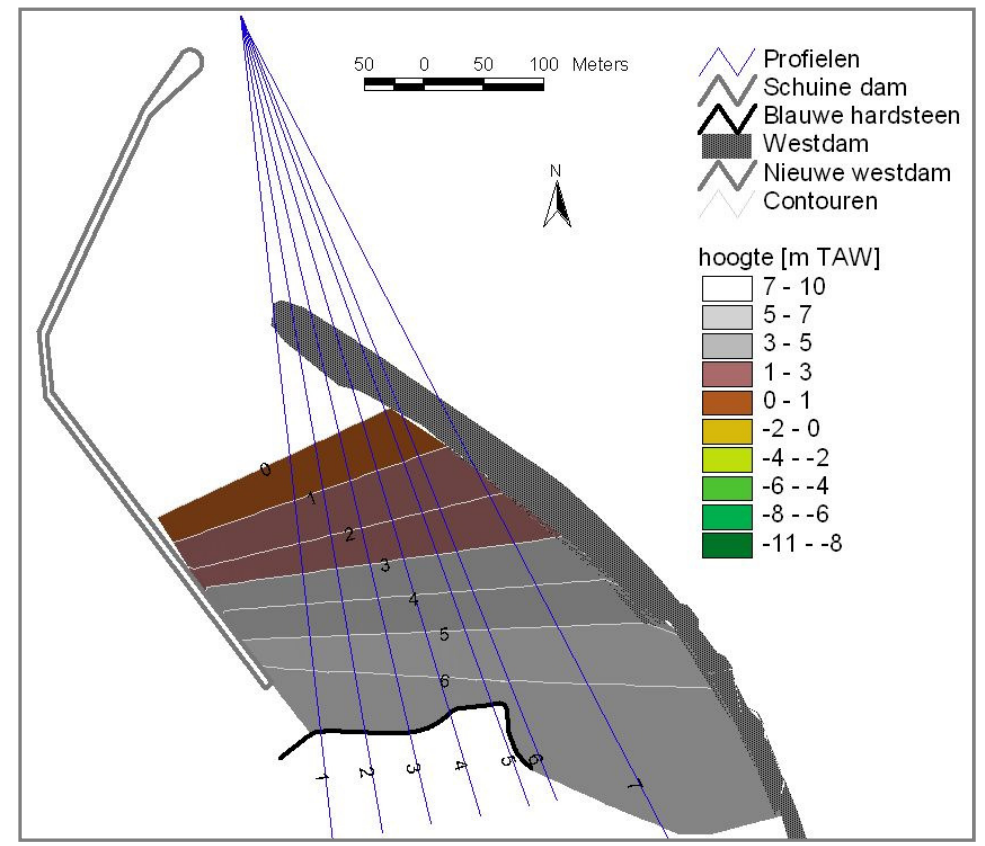

Figure 11 Initial bathymetry and profiles

Using the design conditions at the harbour entrance, Durosta calculations are carried out. This results in a post-storm bottom profile (Figure 12).

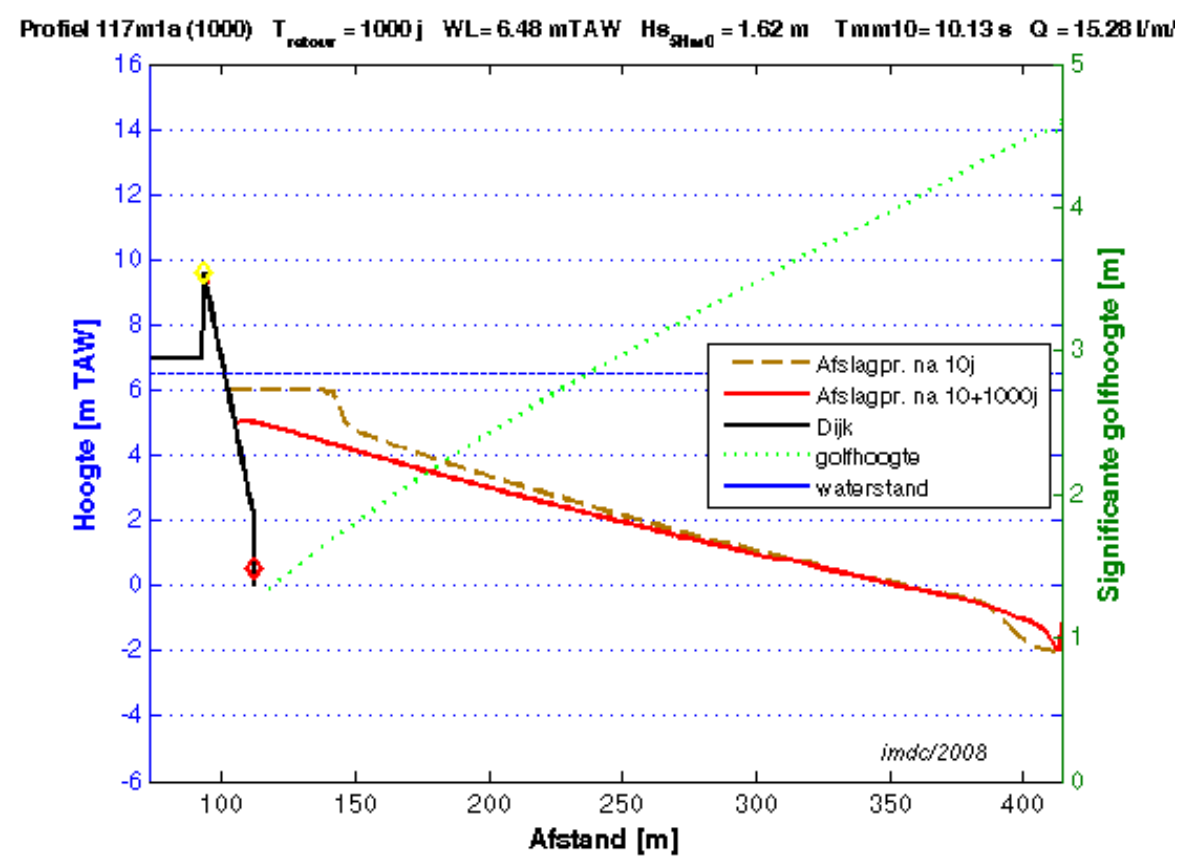

Figure 12 Durosta-result : profile after storm with return period of 10 years (dotted brown), after a storm with return period 1000 year (red line) and evolution of wave height (green)

Doing this calculations for different profiles gives a post storm bottom.

Figure 13 gives an example of a post-storm bathymetry for a situation where the seawall is extended. At the tip of the new seawall a lot of erosion occurs. However, possibly long shore effects will smooth out the contourlines, but in a conservative approach this is neglected. 


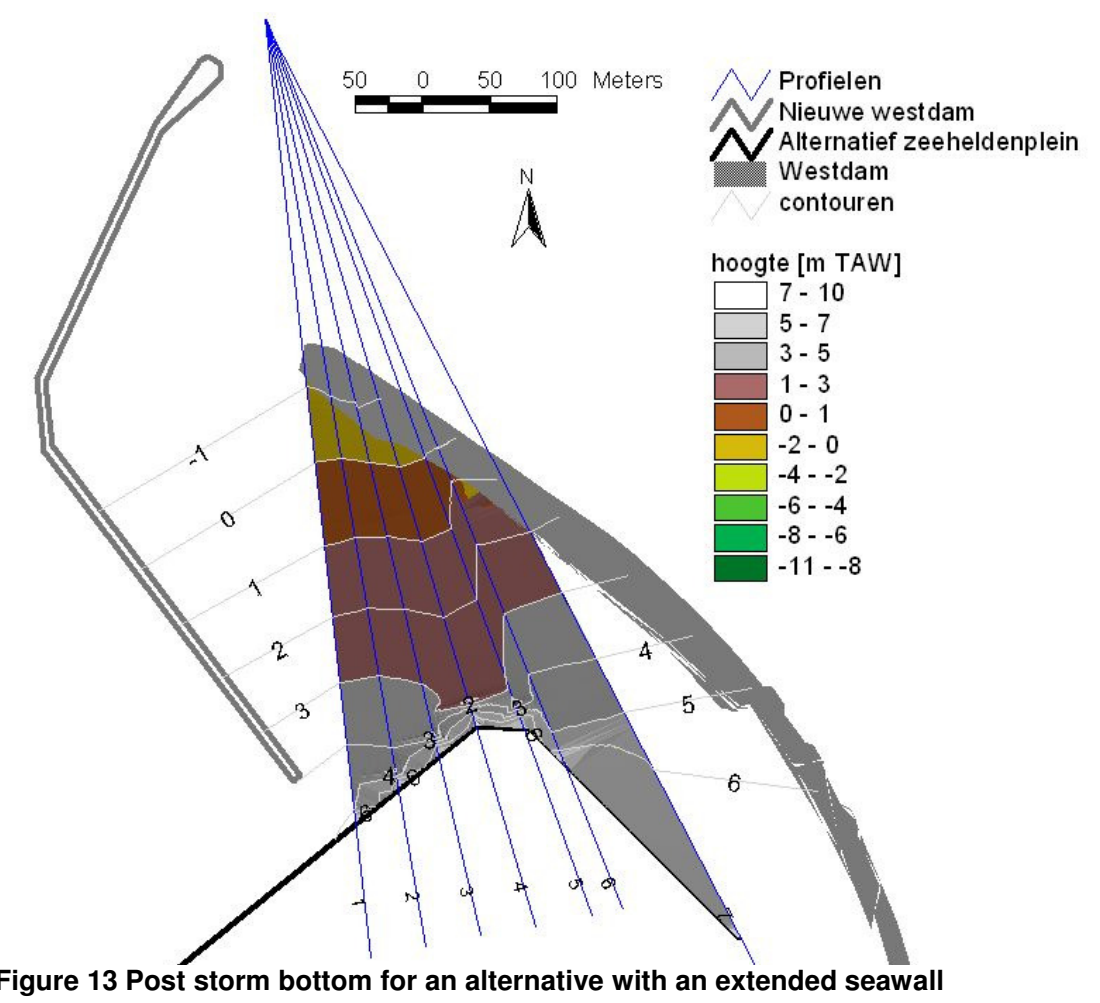

Wave height calculations

The wave height obtained with Durosta is an overestimation (and for this reason also the erosion might be overestimated) since diffraction will cause a spreading of wave energy. For this reason, a diffraction wave model is used to estimate the wave height in front of the sea wall (Figure 14).

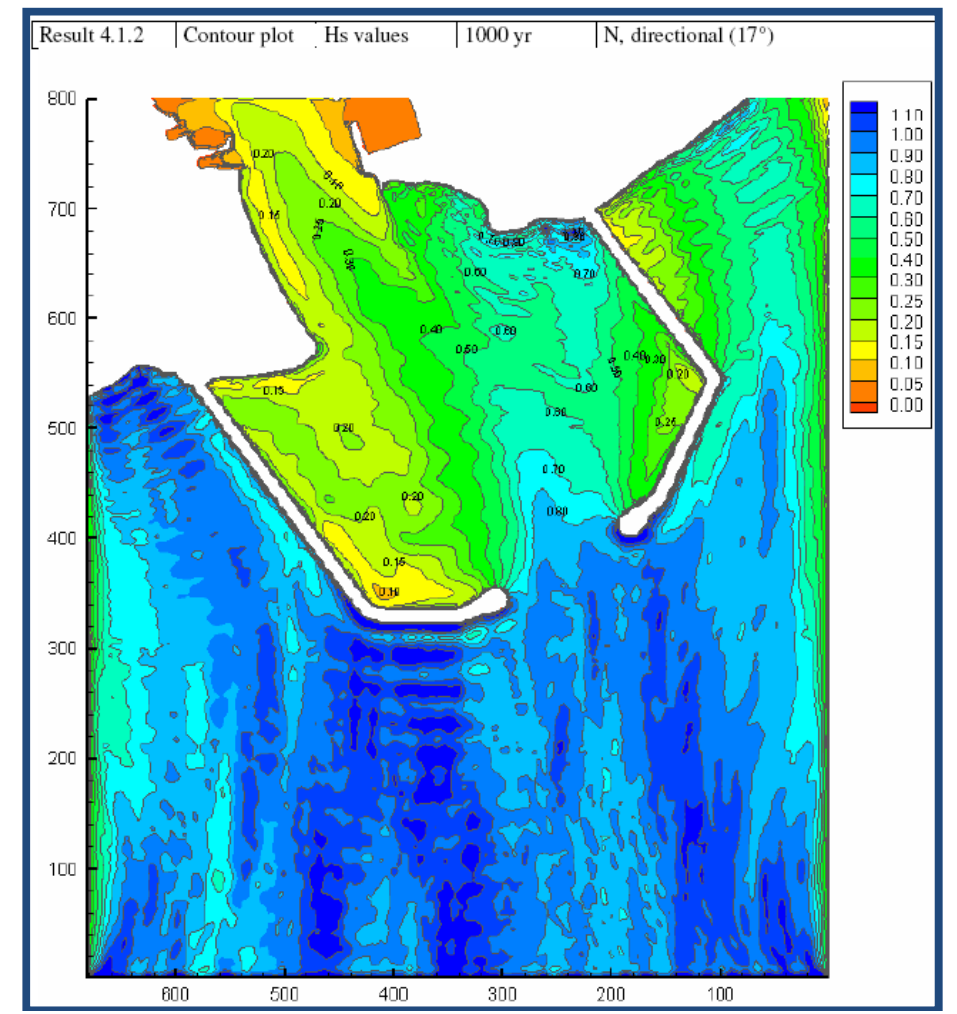

Figure 14 Diffraction model results (diffraction coefficient) 


\section{Overtopping discharges}

In order to limit the overtopping discharge the concept of a stilling wave basin is used (Van Doorslaer, 2009) A stilling wave basin (SWB) is made up of a vertical seaward wall, a basin and a 2nd landward wall. Waves hitting the seaward wall are projected upward and "drop dead" in the basin and lose their energy. Since the seaward wall is actually a double row of shifted walls, the evacuation of the overtopped water is possible. In case of large overtopping, the water runs back and forth the basin between the seaward and the landward wall, meanwhile losing its energy. The remaining energy is insufficient to overtop the landward wall. An important parameter in this SWB is the blocking coefficient, which is the ratio between the open and the closed part of both rows of shifted walls. The optimum between inflow (as low as possible) and outflow (as high as possible) needs to be found.

An example is shown in Figure 15. The effect on the overtopping discharge is shown in Figure 16.

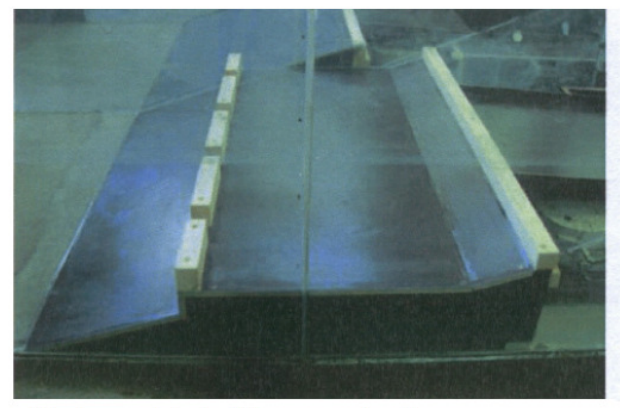

Scale model of stillina wave basin

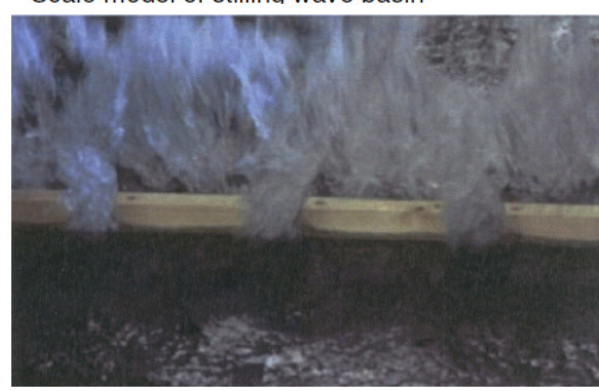

wave attack on seaward wall

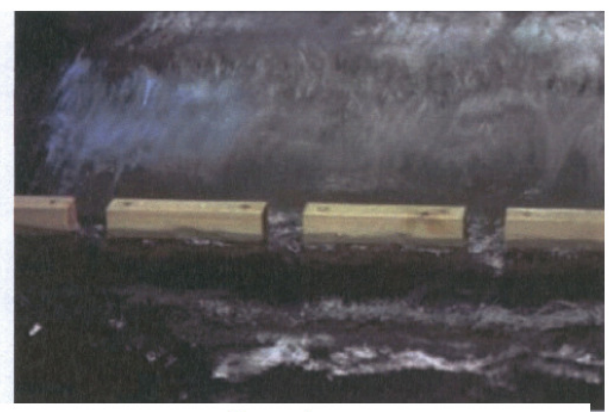

Incomina wave

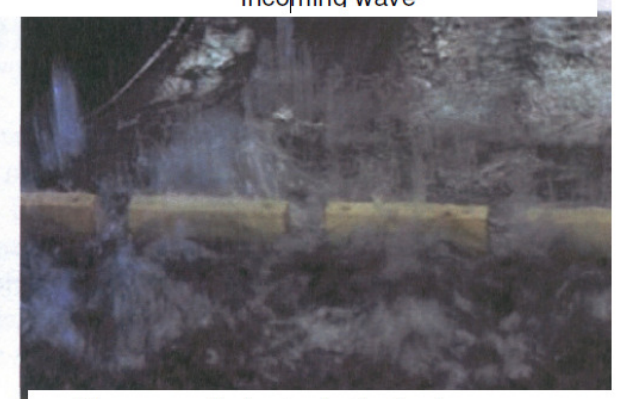

The wave dissipates in the basin

Figure 15 Principle of the stilling wave basin with photos of the physical model. Left above : the stilling wave basin, right above: incoming wave left below: incoming wave overtops the most seaward wall and right below, the wave dissipates in the basin

The physical model tests indicated that the most seaward wall can be constructed as a bench, where the opening below the seat has to be $20 \%$ of the total verticale surface.

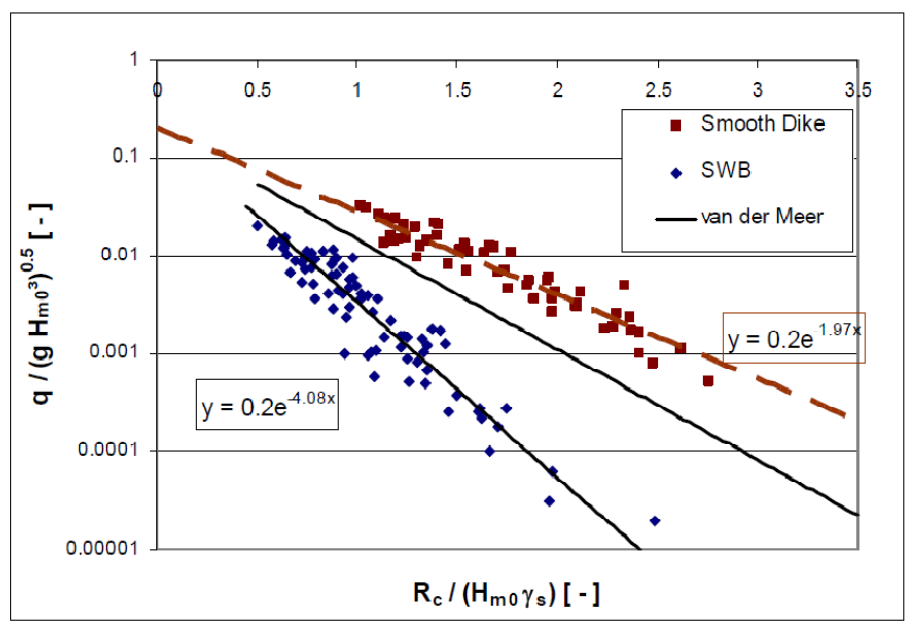

Figure 16 Dimensionless overtopping discharge as a function of dimensionless crest freeboard for both smooth dike and dike + SWB (non-breaking waves) 
This resulted in a typical cross section as presented in Figure 17.

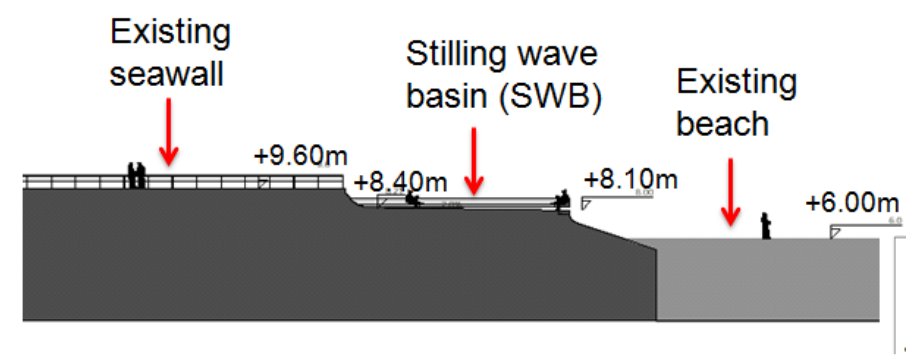

Figure 17 Typical cross section

The construction combines 3 advantages:

- Reduces the overtopping discharge considerably

- Preserves the original outline of the seawall

- Creates an additional promenade

\section{INTEGRATED DESIGN OF THE NEW SEAWALL AND THE WESTERN BREAKWATER}

These coastal protection measures, as well as the design of the western breakwater, had to be integrated in the historical city context during the Environmental Impact Assessment Studies (EIA-process) (Arts et al, 2009). The study of different alternatives and variants results in a mitigated practical solution that will be executed the next years (see Figure 18). The breakwater is located inbetween the red and green alternative, so a Stilling Wave Bassin is still necessary to protect the city.

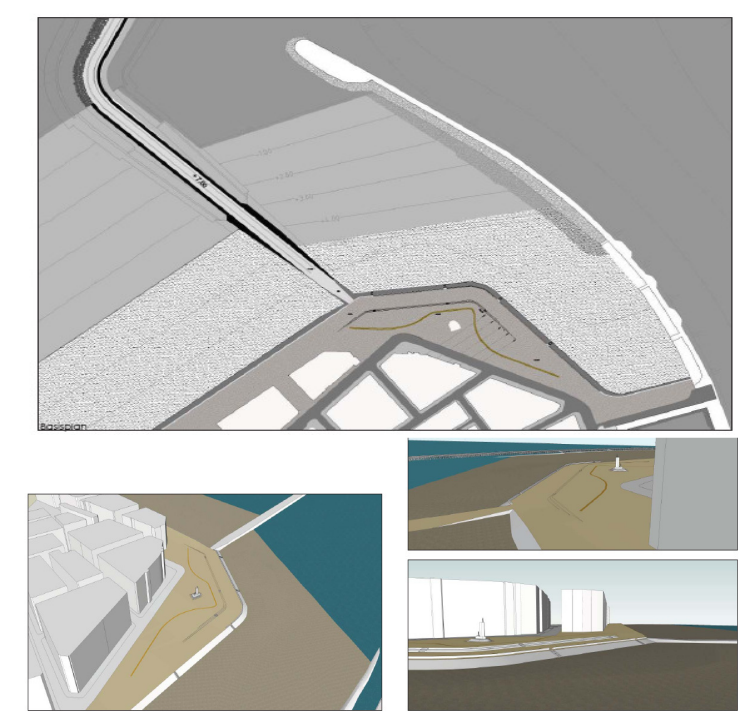

Figure 18: Integrated and mitigated practical solution

\section{LESSONS LEARNED}

During the whole process some lessons are learned:

- Make one contract for technical and EIA studies

- Multidiciplinaire teams of experts are needed : technical experts, architects, urban designers, environmental experts,...

- Involve the stakeholders (Habour of Ostend, Town of Ostend) 
- Searching for alternatives/variants and mitigation measures is needed within the EIAprocedures

- Ask advice at the administrations competent for the legal-administrative procedure

- Independent competent judicial advice during the different project phases is an absolute necessity

- Communication is very important. Do not let opponents set the communication agenda, but bring your own message

- The time consuming legal-administrative procedure made it necessary to execute intermediate measures.

\section{REFERENCES}

Arts, P., Parys, J., Colpaert, R. T. Opdebeek (Soresma), 2009, Kustverdedigingen maritieme toegankelijkheid van oostende - Project-MER - (report in dutch)

Bolle, A., Trouw K., 2008, Haventoegang Oostende - Westelijk Strand (IMDC report in dutch)

Bolle, A., Trouw,K., De Rouck,J., Willems,M. (IMDC- UGent-Flanders Hydraulics), 2009, Haventoegang Oostende - Ontwerp Zeeheldenplein, Havendammen en Groeistrand (report in dutch)

De Rouck, J., Berlamont, J., M. Stive, 2003, Zeedijk Oostende tussen Casino en Klein Strand Advice note of technical experts

Geeraerts, J., De Rouck, J., Gysens, S., Beels, C., DeWolf, P., 2006, Reduction of wave overtopping at seadikes: Stilling Wave Basin (report in dutch)

Steetzel, H. (1993) Cross-shore sediment transport during storm surges, Ph. D. Thesis, TU Delft

Technum- IMDC- Alkyon, 2004, Structureel herstel van Oostende-Centrum en de verbetering van de haventoegang van Oostende - Morfologie (report in dutch)

Troch,P., Vanneste,D., Stratigaki,V., 2009, Design of Oostende Harbour: Numerical Simulation of Wave Propagation - Inside Area Breakwaters (Ugent report)

Van Doorslaer, K., De Rouck, J., Gysens, S., 2009, Reduction of Wave Overtopping: From Research to Practise 4th SCACR Barcelona

Verelst, N., Delgado, R., Janssen, J., Verwaest, T., De Mulder, T., and F. Mostaert. 2009. Hydraulische simulaties voor verschillende varianten van de westelijke dam met een verfijnd Oostende - model: Eindrapport, WL Rapporten, 627_14, Waterbouwkundig Laboratorium, Antwerpen, België.

Verhaeghe, H., Van Damme, L., Goemaere, J., De Rouck, J. Van Alboom, W., Construction of twe new breakwaters at Ostend leading to an improved harbour access, Proceedings of 32nd International Conference on Coastal Engineering, ICCE 2010, ASCE 